\title{
Kebutuhan Literasi Informasi dan Digital bagi Masyarakat di Pekon Podosari Kecamatan Pringsewu Provinsi Lampung
}

\author{
Andi Windah ${ }^{1}$; Purwanto Putra ${ }^{*}$; Renti Oktaria² ${ }^{2}$ Annisa Yulistia ${ }^{2}$ \\ ${ }^{1}$ Program Studi D3 Perpustakaan, Universitas Lampung \\ ${ }^{2}$ Jurusan Pendidikan Guru Pendidikan Anak Usia Dini, Universitas Lampung \\ *Korespondensi: purwanto.putra@ fisip.unila.ac.id
}

\begin{abstract}
This research identifies information and digital literacy needs of the Community in Pekon Podosari, Pringsewu District, Lampung Province. This is important with the assumption that there is still a lack of literacy skills from the people who provide public services due to a lack of guidance in the form of literacy provision, especially information literacy and digital literacy training. In addition, the limited resources of various related agencies responsible for this matter are a major obstacle in advancing human resources in terms of literacy skills, especially for the Pringsewu District and Pringsewu District more broadly. This research is a descriptive study using a qualitative approach. Descriptive to be produced from this research is about descriptive method used to provide a detailed description or explanation of a problem. Data was collected by reviewing relevant literatures. The results showed that the need for implementing the concept of accelerated community literacy in order to overcome various disadvantages. Mastering skills or competencies in the field of information technology is a must in the present. Apart from being an effort to adapt and compete in the era of the industrial revolution 4.0 and the information society 5.0, this is also a filter so that people can mature in information.
\end{abstract}

Keywords: information literacy; digital literacy; seven pillars

\begin{abstract}
Abstrak
Penelitan ini menganalisis tentang Kebutuhan Literasi Informasi Dan Digital Bagi Masyarakat Di Pekon Podosari Kecamatan Pringsewu Provinsi Lampung. Hal ini penting dengan asumsi bahwa masih kurangnya kecakapan literasi dari masyarakat yang memberikan pelayanan publik karena kurangnya pembinaan dalam bentuk pembekalan literasi, khususnya literasi informasi dan literasi digital. Selain itu keterbatasan sumber daya dari berbagai instansi terkait yang bertanggungjawab terhadap urusan ini menjadi penghalang utama dalam memajukan sumber daya manusia dalam hal kecakapan literasi khususnya untuk wilayah Kecamatan Pringsewu dan lebih luas lagi Kabupatan Pringsewu. Penelitian ini dengan menggunakan metode kualitatif dengan tujuan untuk memberikan gambaran atau penjelasan secara terperinci mengenai kebutuhan literasi informasi dan digital bagi masyarakat di Pekon Podosari Kecamatan Pringsewu Provinsi Lampung. Pengumpulan data pada penelitian ini dilakukan melalui kajian literatur. Data yang diperoleh dianalisis dan disusun secara sistematis sesuai dengan tema pembahasan. Hasil analisis menunjukkan bahwa kebutuhan pengimplementasian konsep akselerasi literasi dibutuhkan untuk mengatasi berbagai masalah yang dihadapi masyarakat. Menguasai kecakapan atau kompetensi di bidang teknologi informasi merupakan suatu keharusan dimasa sekarang. Selain sebagai upaya agar dapat beradaptasi dan berkompetisi di era revolusi industri 4.0 dan masyarakat informasi 5.0, hal ini sekaligus sebagai filter agar masyarakat dapat bersikap dewasa dalam berinformasi.
\end{abstract}

Keywords: literasi informasi; literasi digital; seven pillars

\section{PENDAHULUAN}

Pendahuluan Hasil Rapat Koordinasi dan Evaluasi Pencapaian Matrix Percepatan Index Desa Membangun pada akhir tahun 2019 mengungkapkan bahwa sebelas pekon (desa) di Kabupaten Pringsewu masuk dalam kategori tertinggal. Sebelas pekon tersebut tersebar di Kecamatan Pardasuka (Pekon Pardasuka Timur, Pardasuka Selatan, Tanjungrusia, Tanjungrusia Timur, Sukanegeri, Rantau Tijang, Kedaung, dan Selapan) dan Pagelaran Utara (Pekon Way Kunyir, Kamilin, dan Gunung Raya) (Sunaryo, 2019)

Penetapan kategori desa/pekon tertinggal datang dari pemerintah pusat, yang harus bertanggungjawab pembenahannya ada pada pemerintah kabupaten. Hal inilah yang menjadi salah satu target pemerintah daerah di Kabupaten Pringsewu tahun 2020 ini. Jika ditelaah lebih lanjut kategori pekon tertinggal ini dilihat dari sisi kesejahteraan masyarakat yang umumnya 
masih rendah, minimnya pasar atau minimal pusat ekonomi untuk memenuhi sembilan bahan pokok dan minimnya akses kesehatan.

Jika dicermati Pekon Podosari yang merupakan salah satu pekon yang ada di Kacamatan dan Kabupaten Pringsewu memang menjadi objek kajian dalam penelitian ini dan tidak masuk kategori tertinggal. Namun, secara umum hal ini juga berdampak dalam kaitannya dengan percepatan index desa tersebut, sehingga harus ada upaya serius untuk menindaklanjuti permasalahan pekon tertinggal di wilayah Pringsewu. Salah satu yang perlu ditingkatkan tentu adalah peningkatan kapasitas sumber daya manusia yang mesti dilakukan secara koordinatif dan lintas sektor sebagai upaya untuk mengentaskan berbagai wilayah di Kabupaten Pringsewu dari kategori desa tertinggal.

Sejauh ini terkait dengan pertumbuhan dan perkembangan keberinformasian masyarakat di berbagai wilayah Kecamatan Pringsewu masih belum tumbuh secara optimal. Ada potensi lain yang masih bisa terus dikembangkan dengan perlakukan yang tepat berkaitan dengan unsul literasi. Misalnya saja berkenaan dengan website sebagai salah satu media dan sumber informasi keadaanya masih sangat minim yang mensyaratkan kemampuan literasi informasi yang beririsan dengan kemampuan literasi digital. Pada era digital ini, kita dapat mengakses berbagai macam informasi dengan mudah. Tapi tak dipungkiri jika sebagian informasi yang kita dapatkan pun adalah informasi hoax atau berita bohong (Prasanti, April 2018). Maka dari itu kecakapan literasi informasi menjadi semakin krusial dan penting.

Secara sederhana literasi informasi menurut ALA (American Library Asociation), dapat dipahami sebagai sebuah serangkaian kemampuan yang dibutuhkan seseorang untuk menyadari kapan informasi dibutuhkan dan memiliki kemampuan untuk menemukan, mengevaluasi dan menggunakan informasi yang dibutuhkan secara efektif (American Library Association, 1989). Definisi lain Menurut, The Prague Declaration (2003) Literasi Informasi merupakan bagian dari kebutuhan informasi seseorang dan merupakan suatu kemampuan dalam mengidentifikasi, menempatkan, mengevaluasi, mengorganisasi dan untuk mengefektifkan informasi yang ada untuk menyelesaikan masalah, dan diperlukan kembali untuk berpartisipasi secara efektif dalam masyarakat informasi, dan juga merupakan bagian dari dasar hak asasi manusia dalam long life education yang harus terus dikembangkan (UNESCO, 2003).

Masih dalam deklarasi tersebut, literasi informasi, dalam hubungannya dengan akses ke informasi penting dan efektif jika memanfaatkan teknologi informasi dan komunikasi yang artinya juga menuntut kemampuan literasi digital. Kemampuan literasi informasi memainkan peran dalam rangka mengurangi ketidakadilan dalam suatu negara dan antara negara-negara bangsa, dapat pula turut mendukung upaya promosi toleransi dan saling pengertian melalui penggunaan informasi dalam konteks multikultural dan program interdisipline (Rizkinaswara, 2018). Hal senada pernah pula disampaikan Chinwe Anunobi dan Obiora Kingsley Udem yang menjelaskan tentang kompetensi literasi informasi sebagai kombinasi dari pengetahuan, keterampilan dan sikap untuk mengenali kapan dan mengapa informasi dibutuhkan, di mana menemukannya, bagaimana cara mengevaluasi, mengelola dan menerapkannya, mensintesis, menggunakan dan mengkomunikasikannya secara etis dan legal(Anunobi \& Udem, 2014).

Literasi dalam hal ini spesifik terkait literasi informasi secara konteks nasional menjadi langkah penting dalam menutup kesenjangan digital melalui penciptaan warga negara yang melek informasi, masyarakat sipil yang efektif, dan tenaga kerja yang kompetitif. Literasi informasi menjadi perhatian semua sektor masyarakat dan harus disesuaikan oleh masing-masing dengan kebutuhan dan konteks spesifiknya.

Hasil penelitian terkait literasi digital berasal dari penelitian Hestin Oktiani dan Eka Yuda G. (Yuda, 2019) tentang Tata Kelola Website Desa dan Kapasitas Pengelola dalam Memproduksi Konten sebagai Media Informasi dan Promosi Potensi Desa menyimpulkan bahwa kompetensi 
para pengelola website, sebagai individu atau kelompok yang dalam tugas dan kesehariannya berkutat dengan aspek informasi. Dari penelitian tersebut dapat tergambar bahwa kekurangan kemampuan literasi informasi dan literasi digital ternyata turut berdampak dalam hal penciptaan dan pengelolaan konten website seperti artikel, foto, dan video yang masih sangat minim, baik dari sisi kualitas dan kuantitasnya. Padahal dalam praktiknya pekerjaan ini sangat membutuhkan dukungan kecakapan berinformasi dan teknis penelusuran informasi.

Kurangnya kecakapan dalam hal literasi informasi dan literasi digital, yang pada banyak kesempatan merupakan satu kesatuan, ibarat dua sisi mata uang baik secara personal maupun kelompok di dalam organisasi atau lembaga publik menuntut adanya intervensi berupa pembinaan dan pembekalan literasi, khususnya literasi informasi dan literasi digital yang sejalan dengan penelitian ini untuk wilayah administrative pekon atau desa di wilayah Pringsewu. Pembinaan dan pembekalan literasi ini sejatinya menjadi tugas dan tanggung jawab Dinas Kominfo bekerjasama dengan civitas akademika perguruan tinggi, perpustakaan atau para penggiat literasi di lingkungan tersebut.

Kondisi semacam ini penting untuk mendapat prioritas karena keterbatasan jumlah sumber daya manusia yang bertanggungjawab terhadap urusan publik dapat diatasi atau optimalkan dengan meningkatkan kualitas SDM pelayan publik atau aparatur pemerintah khususnya yang ada di wilayah Kecamatan Pringsewu dan lebih luas lagi Kabupatan Pringsewu dalam rangka memajukan sumber daya manusia dan turut mendukung program kesejahteraan masyarakat wilayah tersebut. Maka dari itu hal ini lebih dari cukup untuk dijadikan landasan dalam hal mengimplementasikan konsep dan praktik akselerasi literasi masyarakat demi untuk mengatasi berbagai ketertinggalan tersebut. Sehingga dapat didefinisikan bahwa tujuan dari penelitian ini untuk mengidentifikasi secara konstruktif dan holistik tentang kebutuhan literasi informasi dan digital bagi masyarakat dengan studi kasus di Pekon Podosari Kecamatan Pringsewu Provinsi Lampung. Hal ini penting untuk diteliti karena kecakapan atau kompetensi di bidang teknologi informasi, merupakan suatu keharusan dimasa sekarang. Selain sebagai upaya agar dapat beradaptasi dan berkompetisi di era revolusi industri 4.0 dan masyarakat informasi 5.0, hal ini sekaligus sebagai filter agar masyarakat dapat dewasa dalam berinformasi.

\section{METODE PENELITIAN}

Penelitian ini merupakan penelitian deskriptif dengan menggunakan pendekatan kualitatif. Deskriptif yang ingin dihasilkan dari penelitian ini adalah tentang Kebutuhan Literasi Informasi Dan Digital Bagi Masyarakat Di Pekon Podosari Kecamatan Pringsewu Provinsi Lampung. Metode deskriptif digunakan untuk memberikan gambaran atau penjelasan secara terperinci terhadap suatu masalah. Pengumpulan data pada penelitian ini dilakukan FGD dengan unsur pemerintahan di Pekon Podosari, selain itu dengan diskusi dan soal yang diberikan dari pretest dan post test pelatihan literasi informasi dan digital yang diselenggarakan di Pekon Podosari, Kecamatan Pringsewu yang terut menyertakan muatan kebutuhan literasi masyarakat. Selain itu juga kajian literature, baik dari sumber primer dan skunder. Kerangka teoritis (theoretical framework) dari penelitian ini mengimplementasikan metode literasi informasi (information literacy), model literasi informasi, yang digunakan untuk penelitian ini The Seven Pillars of Information Literacy model konseptual yang dikembangkan di Inggris oleh SCONUL (Standing Conference of National and University Libraries). Model 7 Pilar yang pada prinsipnya terdiri dari 2 himpunan keterampilan yaitu (a) Mengetahui bagaimana menentukan lokasi informasi serta cara mengaksesnya, dan (b) Mengetahui bagaimana memahami serta menggunakan informasi (Bent \& Stubbings, 2011).

Model 7 Pilar ini digunakan dalam penelitian ini dalam rangka untuk membantu dan memudahkan dalam pengumpulan sumber literatur. Secara praktis model literasi informasi ini 
digunakan untuk lebih mendalami terkait pengumpulan data dan informasi agar setiap pemerolehan atau hasil pencarian informasi dapat dimanfaatkan secara maksimal. Data dan informasi yang diperoleh untuk selanjutnya dianalisis dan disusun secara sistematis sesuai dengan tema pembahasan. Selain itu model ini digunakan demi mendapatkan literatur yang berkualitas dalam waktu yang lebih singkat. Penelitian ini juga menggunakan berbagai sumber informasi tercetak dan terekam yang tersaji dalam beragam format. Strategi ini dilakukan dalam rangka memperoleh data dan informasi holistis, yang memiliki keterpaduan hubungan ketika disatukan dalam suatu kerangka penelitian. Penelitian ini menggunakan pendekatan kualitatif dengan metode deskriptif.

Dalam penelitian ini, pengolahan data yang dilakukan mengikuti metode dari Suyanto dan Sutinah yang dilakukan dengan tahapan: (1) reduksi data; merupakan suatu kegiatan kerja untuk menganalisis, menajamkan, menggolongkan, mengarahkan, mensortir data-data untuk mengeliminasi yang tidak dibutuhkan, dan mengorganisasi data dengan sedemikian rupa hingga dapat menarik kesimpulan-kesimpulan awal untuk kemudian diverifikasi. (2) penyajiaan data; penyajian data merupakan salah satu tahapan kegiatan dalam pembuatan laporan hasil penelitian dengan cara kerja sistematis agar data-data hasil temuan penelitan dapat dipahami dan dianalisis sesuai dengan tujuan yang diinginkan. Pada prinsipnya data yang disajikan harus sederhana dan jelas agar mudah dibaca. (3) verifikasi data; merupakan suatu proses penyusunan laporan penelitian yang dipergunakan dalam menilai kebenaran landasan teori dengan fakta di lapangan, untuk kemudian mengolah dan menganalisis berbagai temuan penelitan agar bisa diuji secara hipotesis atau memperbandingkannya dengan teori-teori yang telah ditentukan. (4) interpretasi data; merupakan sebuah kegiatan yang dilakukan dengan membuat penggabungan terhadap sebuah hasil dari analisis dengan berbagai macam pertanyaan, kriteria, maupun pada sebuah standar tertentu guna untuk dapat menciptakan sebuah makna dari adanya sebuah data yang telah dikumpulkan oleh peneliti.

Hasil tahapan-tahapan tersebut di atas kemudian dituliskan sebagai artikel hasil penelitian (Bagong, 2006). Secara lebih mendalam dijelaskan tahapan setelah data dan informasi terkait subjek penelitian dikumpulkan sebagai berikut.

\section{HASIL DAN PEMBAHASAN}

Sebelum beranjank pada literasi informasi perlu dulu secara sederhana dipahami tentang apa itu informasi. Sebagai upaya untuk memberikan definisi informasi yang diterima secara universal, Ojedokun (2007) mengemukakan bahwa informasi adalah pernyataan fakta, figur, gagasan, dan karya kreatif dari akal manusia, yang secara logis atau secara penalaran saling terkait, dan telah dikomunikasikan secara formal atau informal dalam format apapun(Ojedokun, 2007). Selain itu, Norman (seperti dikutip dalam Owusu-Ansah, 2003) mendefinisikan informasi sebagai data faktual, ide, dan pengetahuan lain yang berasal dari masyarakat mana pun yang diidentifikasi sebagai yang bernilai, terkadang dikumpulkan secara teratur, diatur dalam beberapa cara, ditransmisikan ke orang lain, dan digunakan dengan cara yang bermakna(Owusu-Ansah, 2003).

Kemampuan literasi khususnya literasi informasi dan literasi digital bertujuan untuk memudahkan dalam melakukan berbagai hal yang berhubungan dengan kegiatan informasi. Menurut Adam (2009), literasi informasi memiliki beberapa manfaat, antara lain sebagai berikut: membantu dalam pengambilan keputusan; menjadi manusia pembelajar di era ekonomi pengetahuan; menciptakan pengetahuan baru (Adam, 2009).

Pada dasaranya jika mengacu kepada Putu L. Pendit (2008), terdapat beberapa jenis keterampilan literasi informasi, yaitu: Tool literacy, Resources literacy, Social structural literacy, Research literacy, Publishing literacy, Emerging technology literacy, dan Critical literacy. Jika 
ditelusur secara terpadu berbagai jenis kecapapan literasi informasi ini juga beririsan sangan dalam dengan bidang kerja literasi digital (Pendit, 2008).

Sebelum dibahas mengenai bagaimana kebutuhan masyarakat Podosari Kecamatan Pringsewu terhadap literasi informasi perlu pula dirumuskan tentang langkah-langkah literasi informasi, sebagai sesuatu struktur inherent atas kecenderungan kebutuhan akan literasi. Menurut Arga (2009), keterampilan literasi informasi diperoleh dengan langkah-langkah tahapan berikut ini: mendefinisikan kebutuhan informasi, menetapkan strategi pencarian, mengumpulkan sumbersumber, menilai dan memahami informasi, menerjemahkan informasi, mengkomunikasikan informasi, dan mengevaluasi produk prosesnya Berdasarkan situasi tersebut pada penelitian ini dijelaskan tiga bahasan yang menjadi kebutuhan masyarakat di Pekon Pedosari berkenaan dengan literasi informasi.

\section{Kebutuhan Kecakapan Literasi Bagi RDS (Rumah Sehat Desa) Pekon Pedosasari- Pringsewu}

Dalam ranah inovasi pengembangan Sumber Daya Manusia (PSDM) di Pekon Pedosari, Kecamatan Pringsewu yang berkaitan dengan literasi, memang digolongkan cukup aktif. Di Pekon Pedosari ini rutin mengelar rapat koordinasi rutin bulanan yang diinisiasi oleh Tenaga Pendamping P3MD Kabupaten Pringsewu dan diikuti berbagai pihak, yang terdiri dari Tenaga Ahli (TA), Pendamping Desa Pemberdayaan (PDP), Pendamping Desa Tenaga Infrastruktur (PDTI) dan Pendamping Lokal Desa (PLD) Se-kabupaten Pringsewu, biasanya dilaksanakan di Balai Pekon Podosari, Kecamatan Pringsewu (Gemalampung.com, 2019).

Pada rakor tersebut dilakukan juga pembentukan Rumah Desa Sehat (RDS) dan Literasi. RDS merupakan sekretariat bersama karena tidak ada lembaga atau individu yang secara khusus yang dapat menyelesaikan persoalan PSDM terutama dalam pemenuhan 5 paket layanan, diantaranya yaitu PAUD, kesehatan ibu dan anak, perlindungan sosial, air bersih dan sanitasi, serta konseling gizi terpadu. Dalam rangka itu maka dibutuhkan wadah atau forum konvergensi terpadu.

Forum atau wadah semacam ini menjadi ruang dialog masyarakat dengan pemerintah desa terkait realitas masalah dan kebutuhan pemenuhan layanan sosial dasar di desa termasuk urusan literasi masyarakat Pekon Pedosari. Aspek literasi merupakan hal yang urgent atau penting sebagai kapabilitas yang mesti dimiliki.

Dalam konteks Rumah Desa Sehat (RDS) yang terbentuk dari hasil musyawarah desa dan disahkaan oleh ketetapan surat keputusan Kepala Desa. RDS memiliki anggota yang terdiri dari berbagai perwakilan dari masyarkat yang berasal dari unsur pegiat pemberdayaan masyarakat dan pelaku pembangunan desa. Keberadaan pegiat pemberdayaan masyarakat dan pelaku pembangunan desa selain pengalaman pada bidangnya tentu menuntut kecakapan literasi informasi dan literasi digital karena adopsi teknologi dan informasi yang sudah tidak terhindarkan lagi dari keseharian mereka.

Pada dasarnya keberadaan RDS berfungsi juga sebagai pusat pelayanan sosial dasar di desa khususnya bidang kesehatan, menjadi ruang literasi kesehatan di desa, forum advokasi kebijakan pembangunan desa di bidang kesehatan dan pusat pembentukan dan pengembangan kader pembangunan manusianya, sehingga dukungan kecakapan literasi merupakan suatu keharusan agar hasilnya dapat lebih optimal dalam memberikan pelayanan kepada masyarakat yang membutuhkan. 


\section{Kebutuhan Kemampuan Literasi Program Desa atau Kelurahan Sadar Hukum di Pekon Pedosasari-Pringsewu}

Ada 12 Pekon dan 1 Kelurahan dari 5 kecamatan di Kabupaten Pringsewu yang dinobatkan sebagai Pekon dan Kelurahan Sadar Hukum. Anugerah tersebut diselenggarakan pada September 2018 di Bandar Lampung untuk seluruh desa dan kelurahan lainnya se-Provinsi Lampung, diresmikan oleh Menteri Hukum dan Hak Asasi Manusia RI Yasonna H. Laoly yang diwakili oleh Pelaksana Tugas Kepala Badan Pembinaan Hukum Nasional Benny Riyanto.

Kedua belas pekon dan satu kelurahan di wilayah Pringsewu tersebut adalah Pekon Pujiharjo, Lugusari, Gemahripah dan Pamenang di Kecamatan Pagelaran, kemudian Pekon Fajaragung, Podosari dan Kelurahan Pringsewu Selatan di Kecamatan Pringsewu, selanjutnya Pekon Margosari dan Giritunggal di Kecamatan Pagelaran Utara, kemudian Pekon Selapan, Sidodadi dan Sukorejo di Kecamatan Pardasuka, serta Pekon Tegalsari di Kecamatan Gadingrejo (Hapsara, 2018).

Menjadi Desa atau Kelurahan Sadar Hukum. Selain itu ada beberapa turunan kegiatan yang berkaitan dengan sadar hukum tersebut, salah satunya adalah pengukuhan Duta Hak Asasi Manusia Provinsi Lampung. Makna Desa atau Kelurahan Sadar Hukum merupakan desa atau kelurahan yang telah dibina atau karena swakarsa dan swadaya, telah memenuhi kriteria sebagai Desa Sadar Hukum dan Kelurahan Sadar Hukum. Maka dalam konteks kesadararan hukum masyarakat itu maka tentu membutuhkan daya dukung literasi yang berkelanjutan agar masyarakatnya senatiasi menjadi individu-individu yang melek dan mengedepankan prilaku taat hukum.

Pada prinsipnya suatu pekon, desa atau kelurahan binaan dapat ditetapkan menjadi Desa Sadar Hukum atau Kelurahan Sadar Hukum jika diusulkan oleh bupati atau walikota setempat setelah memenuhi persyaratan yang ditetapkan berdasarkan keputusan Kepala Badan Pembinaan Hukum Nasional. Jika menukik pada pengkhususan untuk wilayah Pekon Podosari, juga masuk sebagai salah satu pekon dari dua belas pekon terpilih di wilayah Kabupaten Pringsewu.

Dasar pembentukan Desa atau Kelurahan Sadar Hukum adalah Peraturan Menkumham Nomor PHN.HN.03.05-73 Tahun 2008 Tentang Pembentukan dan Pembinaan Keluarga Sadar. Jika ditelaah lebih lanjut dari peraturan Menkumham ini ditemui juga suatu istilah terkait Keluarga Sadar. Sehingga dari konteks tersebut ada kebutuhan literasi yang dimensinya jauh lebih luas dari spektrum individu menjadi keluarga. Dalam konteks praktiknya tentu ada kebuthan yang lebih luas berkenaan dengan literasi yang cakupannya pada unsur keluarga. Jika menelusur tujuan dari penetapan Desa dan Kelurahan Sadar Hukum ini merupakan upaya untuk menguatkan keberadaan Indonesia sebagai Negara Hukum. Suatu upaya yang menuntut pemahaman dan keterampilan literasi bagi masyarakat yang ada di dalamnya.

Persoalannya, kemandirian masyarakat kita terutama pada lingkup pekon atau desa, khususnya yang ada di Kabupaten Pringsewu ini. Sekaligus harus ada upaya untuk lebih mensinergikan dan meneguhkan upaya bersama dalam membangun masyarakat yang cerdas hukum melalui dimensi literasi. Ada harapan pula dari Pemerintah Daerah Kabupaten Pringsewu dan para pemangku kepentingan untuk desa-desa dan kelurahan yang telah ditetapkan sebagai Desa Sadar Hukum yang dapat menjadi percontohan bagi desa atau kelurahan lainnya di Provinsi Lampung khusunya melalui daya dukung aspek literasi informasi dan literasi digital.

\section{Kebutuhan Pada Perpustakaan Untuk Menunjang Literasi Informasi dan digital Masyarakat Pekon Podosari Kecamatan Pringsewu}

Dampak dari perkembangan teknologi informasi yang mengakibatkan ledakan informasi dan lahirnya masyarakat informasi tidak dapat lagi dibendung karena informasi bisa saja berada 
dalam genggaman setiap orang melalui perantara telepon pintar, termasuk bagi masyarakat Pekon Podosari Kecamatan Pringsewu, Provinsi Lampung tentunya.

Setiap orang dapat menerima informasi apapun dan dari manapun tanpa batas. Ketersedian berbagai bentuk media dan sumber informasi, bagi masyarakat menjadiakan terciptanya berbagai pilihan yang lebih luas guna mendapatkan informasi yang mereka inginkan. Kemajuan teknologi informasi seolah-oleh membuat orang dapat mengetahui berbagai hal yang ingin mereka ketahui dengan segera, dapat dikatakan bahwa informasi saat ini seperti kebutuhan pokok bagi segiap orang. Namun, tidak sedikit pula persoalan yang timbul karena fenomoena ini seperti halnya berita bohong atau hoax yang bisa timbul dan menyebar di dalam lingkunga masyarakat

Proses pemenuhan kebutuhan informasi akan berhasil dengan maksimal jika masyarakat memahami konsep dan praktik literasi informasi. Dalam konteks ini kita dapat kembali mendudukan makna dari literasi informasi pada dimensi yang amat luas yang didalamnya termasuk literasi digital. Dapat pula dikatakan bahwa literasi informasi tersebut merupakan kesatuan dengan literasi digital karena dalam literasi informasi juga mensyaratkan kemelekan teknologi informasi, berpikiran kritis dan peka terhadap lingkungan, atau bahkan peka dan kritis pula terhadap perkembangan ekonomi atau bakan politik.

Hal utama dalam membuat perlunya literasi informasi adalah kebutuhan seseorang akan kemampuan belajar terus menerus (life long learning) dan penuh kemandirian agar dapat hidup sukses dalam masyarakat informasi. Sungguhnya dalam konsep belajar sepanjang hayat dapat diartikan sebagai belajar dengan tujuan untuk melakukan perubahan cara pikir dan tingkah laku.

Perpustakaan sebagai salah satu sumber belajar yang dituntut untuk mampu menyediakan berbagai informasi mengenai perkembangan ilmu pengetahuan dan teknologi yang ada diseluruh bumi dari zaman ke zaman. Perkembangan teknologi informasi dokumen-dokumen yang tercetak (hardcopy) dapat diubah menjadi dokumen digital (softcopy) demikian juga sebaliknya. Selain itu perpustakaan juga bisa berada pada lingkup geografis yang terkecil seperti halnya yang ada ditingkat pekon dan tetap dapat dikelola secara profesional.

Perkembangan teknologi informasi dan komunikasi kondisi ini juga membawa perubahan yang bersifat fundamental dalam bidang perpustakaan. Teknologi informasi dan komunikasi tidak dapat lagi dihindarkan dari perpustakaan saat ini dan masa mendatang jika perpustakaan ingin tetap ada dan tidak berakhir dengan ditinggalkan pemustakanya. Pengaruh perkembangan teknologi terhadap perpustakaan banyak dirasakan, baik pengaruh menuju efesiensi dan efektifitas maupun pengaruhnya terhadap kesiapan pustakawan dan pengguna perpustakaan.

Teknologi informasi dan komunikasi di perpustakaan tidak hanya berfungsi sebagai sarana pendukung untuk meningkatkan pelayanan, tetapi juga menjadi perantara dalam memberikan layanan kepada pengguna. Perkembangan teknologi informasi dan komunikasi juga berkaitan erat dengan perubahan sikap atau perilaku dan kemampuan pengguna dalam mencari informasi yang dibutuhkannya.

Pada era informasi saat ini setiap orang dituntut untuk 'melek informasi' sehingga diperlukan kemampuan untuk mendapatkan dan mengelola informasi dan kemampuan menggunakan perangkat teknologi informasi. Oleh karena itu perpustakaan dapat menjadi hub atau penghubung antara keberinformasian masyarakat di Pekon Pedosari dengan informasi hasil digitalisasi (e-library) dalam hal konten yang dikoleksi perpustakaan. Keberadaan perpustakaan pada hakikatnya sangat dibutuhkan dalam rangka mendukung untuk melatih masyarakat agar dapat berinformasi secara benar sekaligus menjadi pusat pengetahuan (knowledge center) bagi masyarakat di Pekon Podosari dan desa sekitarnya.

Perkembangan perspustakaan menuju konsep yang serba digital, dengan ciri tempat yang efisien, kaya informasi dan koleksi serta dapat menembus batasan ruang dan waktu dapat diakses 
oleh siapapun dari manapun dan kapanpun dengan syarat dan ketentuan yang berlaku yang tetap menicirikannya sebagai perpustakaan.

Literasi informasi sangat diperlukan karena peningkatan yang sangat tajam akses informasi dan sumber-sumbernya. Setiap orang dihadapkan dengan pilihan-pilihan informasi yang bermacam-macam dan membludak di dalam belajarnya, tempat kerjanya dan dalam kehidupan mereka. Keberadaan perpustakaan oleh karenanya sangat dibutuhkan oleh pengguna untuk menyediakan berbagai informasi yang dibutuhkan oleh pengguna.

Perpustakaan sebagai pengelola perpustakaan dituntut tidak hanya terampil menhurusi buku namun juga dituntut untuk bisa menguasai teknologi informasi (TI). Dengan menguasai teknologi informasi pustakawan akan menguasai penelusuran literasi informasi. Dengan keterampilan yang dimiliki pustakawan akan bisa membimbing dan mengajari pengguna perpustakaan untuk menemukan sumber-sumber informasi yang dibutuhkan.

\section{SIMPULAN}

Masyarakat yang memberikan pelayanan kepada masyarakat di wilayah Pekon Podosari Kecamatan Pringsewu Provinsi Lampung membutuhkan kecakapan dan keterampilan literasi informasi dalam menunjang kompetensi dan profesionalismenya dalam pelayanan publik dan dalam rangka meningkatkan daya saing yang adaptif di era revolusi industri 4.0 dan masyarakat informasi 5.0.

Literasi informasi dan literasi digital memiliki irisan pada urusan penelusuran informasi berbasiskan sumber informasi digital atau yang tersedia diberbagai pangkalan data. Memberikan pembekalan keterampilan penelusuran informasi pada database Google dengan menggunakan strategi penelusuran lanjutan. Merupakan hal yang dirasa tepat dan penting untuk diberikan kepada publik di Pekon Podosari, khususnya pihak-pihak yang berhubungan atau bertugas memberikan layanan publik bagi masyarakatnya.

Kebutuhan literasi informasi dan literasi digital sekaligus akan berperan sebagai filter agar masyarakat dapat semakin dewasa dalam berinformasi. Literasi informasi dan literasi digital saling berkaitan dan terhubung, literasi informasi secara sederhana dapat disimpulkan sebagai bentuk kemampuan seseorang individu untuk mengenali informasi yang dibutuhkan dan kemampuan untuk menemukan dimana informasi tersebut berada, kemudian mengevaluasi dan juga mampu menggunakan informasi tersebut secara efektif. Dalam hal penemuan dan akses terhadap sumber-sumber informasi secara umum dan pertimbangan praktis mengikuti pola prilaku masyarakat adalah dengan menggunakan sumber atau pangkalan data elektronis atau digital. Sehingga dapat pula disimpulkan bahwa literasi informasi dan literasi digital merupakan dua konsep berbeda yang saling berkorelasi dalam kerangka konsep revolusi industri 4.0 dan masyarakat informasi 5.0.

\section{DAFTAR PUSTAKA}

Adam. (2009). Literasi Informasi. . Diambil kembali dari http://perpus.umy.ac.id/: http://perpus.umy.ac.id/2009/2/19/lietraasi=informasi/

American Library Association. (1989, January 10). ALA Presidential Committee on Information Literacy: Final Report,. Washington, D.C.: American Library Association.

Anunobi, C., \& Udem, O. K. (2014). Information Literacy Competencies: A Conceptual Analysis. Journal of Applied Information Science and Technology, Vol. 7(2), 64-80.

Bagong, S. d. (2006). Metodologi Penelitian Sosial Berbagai Alternatif Pendekatan. Jakarta: Prenada Media Group. 
Edy. (2018, September 26 ). Pekon Podosari Genjot Pembangunan. Diambil kembali dari https://haluanlampung.com: https://haluanlampung.com/2018/09/26/pekon-podosari-genjotpembangunan/

Gemalampung.com. (2019, September 24). Tenaga Pendamping P3MD Kabupaten Pringsewu Ikuti Rakor dan IST Pembentukan RDS dan Literasi. Diambil kembali dari https://gemalampung.com: https://gemalampung.com/tenaga-pendamping-p3md-kabupatenpringsewu-ikuti-rakor-dan-ist-pembentukan-rds-dan-literasi/uncategorized/

Hapsara, I. (2018, September 13). 12 PEKON \& 1 KELURAHAN DI PRINGSEWU DIRESMIKAN SEBAGAI DESA SADAR HUKUM. Diambil kembali dari https://www.pringsewukab.go.id/: https://www.pringsewukab.go.id/detailpost/12-pekon--1-kelurahan-di-pringsewudiresmikan-sebagai-desa-sadar-hukum

Kuhlthau, C. C. (2007). Information Search Process. Dipetik February 22, 2016, dari Information Search Process: http://comminfo.rutgers.edu/ kuhlthau/information_search_process.htm.

Moleong, L. J. (2011). Metodologi Penelitian Kualitatif . Bandung: Remaja Rosdakarya.

Ojedokun, A. A. (2007). Information literacy for tertiary education students in Africa. Ibadan: Third world information services limited.

Owusu-Ansah, E. (2003). Information literacy and the academic library: a critical look at a concept and the controversies surrounding it. The Journal of Academic Librarianship, 29(4). Diambil kembali dari http://www.sciencedirect.com/219230

Pendit, P. L. (2008). Perpustakaam Digital - dari A sampai Z. Jakarta: Cita Karyakarsa Mandiri.

Prasanti, D. (April 2018). Health Information of Literation as Prevention Processes of Hoax Information in the Use of Traditional Medicine in Digital Era. Jurnal Pekommas, Vol. 3 (1), $45-52$.

Rizkinaswara, L. (2018, November 13). Literasi Digital Pilar Masyarakat Informasi Indonesia. Diambil kembali dari https://aptika.kominfo.go.id/: https://aptika.kominfo.go.id/2018/11/literasi-digital/

Sugiyono. (2012). Metode Penelitian Kunatitatif Kualitatif dan $R \& D$. Bandung: Alfabeta.

Sunaryo, A. (2019 , 12 Desember). 11 Pekon di Pringsewu Masuk Kategori Tertinggal. Diambil kembali dari https://www.lampost.co/: https://www.lampost.co/berita-11-pekon-dipringsewu-masuk-kategori-desa-tertinggal.html

Tungka, R. Y. (Penulis), \& TV, T. K. (Sutradara). (2013). 100 Hari Keliling Indonesia Eps 1 Part 2 [Gambar Hidup]. Indonesia. Diambil kembali dari https://www.youtube.com/watch?v=1xWFQC6WwD8

UNESCO. (2003). The Prague Declaration "Towards An Information Literate Society". Praha, Republic Ceko: US National Commission on Library and Information Science and the National Forum on Information Literacy.

World Bank. (1998). Indigenous Knowledge For Development : A Frame Work For Action. Africa Region : World Bank Knowledge and Learning Center.

Yuda, H. O. (2019). Tata Kelola Website Desa dan Kapasitas Pengelola dalam Memproduksi Konten sebagai Media Informasi dan Promosi Potensi Desa (Studi Kasus pada Pengelolaan dan Kompetensi Pengelola Website Desa di Kecamatan Pringsewu Kabupaten Pringsewu). Bandar Lampung: Universitas Lampung.

Yusuf, P. M. (1988). Pedoman Praktis Mencari Informasi. . Bandung: Remaja Rosdakarya.

Yusup, P. M., \& Subekti, P. (2010). Teori \& Praktek Penelusuran Informasi: Informasi Retrieval. Jakarta: Kencana. 
Lentera Pustaka: Jurnal Kajian Ilmu Perpustakaan, Informasi dan Kearsipan, 6 (2) 2020, 159-168 